\title{
Serum Levels of Homocysteine in Young Psoriasis Patients Naïve for Conventional Systemic and Biologic Therapy
}

\author{
Maja Tolušić Levak ${ }^{1,2}$, Vera Plužarićc ${ }^{1}$, Ivana Krajina ${ }^{1}$, Marija Šola $^{1,3}$, Stana Tokić ${ }^{4}$, \\ Marija Delaš Aždajićs, Hrvoje Brajčićc ${ }^{6}$, Ivanka Muršić ${ }^{1}$, Mirna Šitum ${ }^{5,7}$, \\ Martina Mihalj ${ }^{1,8}$ (D) \\ ${ }^{1}$ Department of Dermatology and Venereology, University Hospital Osijek, Osijek, Croatia \\ ${ }^{2}$ Department of Histology and Embryology, Faculty of Medicine Josip Juraj Strossmayer University of Osijek, Osijek, Croatia \\ ${ }^{3}$ Department of Dermatology and Venereology, Faculty of Medicine Josip Juraj Strossmayer University of Osijek, Osijek, \\ Croatia \\ ${ }^{4}$ Department of Medical Chemistry, Biochemistry and Clinical Chemistry, Faculty of Medicine Josip Juraj Strossmayer Uni- \\ versity of Osijek, Osijek, Croatia \\ ${ }^{5}$ Department of Dermatology and Venereology, Sestre milosrdnice University Hospital Center, Zagreb, Croatia \\ ${ }^{6}$ Department of Infectiology and Dermatovenereology, General Hospital Dubrovnik, Dubrovnik, Croatia \\ ${ }^{7}$ Department of Dermatology and Venereology, Faculty of Dental Medicine University of Zagreb, Zagreb, Croatia \\ ${ }^{8}$ Department of Physiology and immunology, Faculty of Medicine Josip Juraj Strossmayer University of Osijek
}

OPEN ACCESS

Correspondence:

Mihalj Martina MD PhD martina.mihalj@gmail.com orcid.org/0000-0002-5734-5849

This article was submitted to RAD CASA - Medical Sciences as the original article

Conflict of Interest Statement: The authors declare that the research was conducted in the absence of any commercial or financial relationship that could be construed as a potentia conflict of interest.

Received: 22 April 2020 Accepted: 24 June 2020 Published: 22 July 2020

Citation:

Tolušić Levak M, Plužarić V, Krajina I, Šola M, Tokić Š, Delaš Aždajić M, Brajčić $H$, Muršić $I$, Šitum $M$ and Mihalj M. Serum levels of homocysteine in young psoriasis patients naïve for conventional systemic and biologic therapy RAD CASA - Medical Sciences. $543=50-51(2020): 17-24$ DOI: https://dx.doi.org/10.21857/ mjrl3u7v39

Copyright (C) 2020 Tolušić Levak M Plužarić V, Krajina I, Šola M, Tokić S, Delaš Aždajić M, Brajčić H, Muršic I, Šitum M and Mihalj M. This is an open-access article distributed under the terms of the Creative Commons Attribution License (CC BY). The use, distribution or reproduction in other forums is permitted, provided the original author(s) and the copyright owners(s) are credited and that the original publication in this journal is criginal publication in this journal is acemic practice or reproduction is permitted which or reproduction is permitted which
does not comply with these terms.

\section{ABSTRACT:}

Introduction: Psoriasis is an immune-mediated chronic inflammatory disease, affecting approximately $1-3 \%$ of the population worldwide. Psoriasis patients are more likely to be diagnosed with cardiovascular diseases and hyperhomocysteinemia; however, it remains elusive weather serum homocysteine levels correlate to disease activity and duration of disease. The aim of this study was to investigate serum levels of homocysteine in young patients with plaque psoriasis naïve for conventional systemic and biologic therapy. An additional aim was to determine correlation of homocysteine levels with disease severity, inflammation, folic acid and vitamin B12 supplies.

Materials and methods: 26 subjects were enrolled to participate in this case-control study, including 13 adult psoriatic patients naïve for systemic therapy, without comorbidities, malignancies and infectious diseases, and 13 healthy unrelated, age and sex-matched volunteers. The disease severity and life quality were assessed using standardized tools - Psoriasis Area and Severity Index (PASI) and Dermatology Life Quality Index (DLQI), respectively. Venous blood was collected and processed for analysis of differential blood count (DBC), erythrocyte sedimentation rate (ESR), C reactive protein (hsCRP), serum levels of homocysteine, vitamin B12 and folic acid in the routine clinical laboratory.

Results Studied cohort consisted of young participants with average age around 35 years. According to the PASI index, disease severity ranged from mild (2.10) to moderate (15.2). There was no significant difference in hsCRP and DBC levels between the groups. Psoriasis patients had significantly higher levels of homocysteine compared to healthy subjects, but there was no evidence of hyperhomocysteinemia related to psoriasis. All subjects had normal serum levels of vitamin B12 and folic acid. A moderate negative correlation was found between plasma homocysteine level and vitamin B12 and folic acid. Furthermore, homocysteine levels did not correlate to hsCRP, total leukocytes, and thrombocytes count, but did significantly positively correlate to ESR.

Conclusions: The risk of cardiovascular diseases should be considered among all psoriasis patients, regardless of age and disease severity, but larger prospective controlled studies are needed to estimate the role of homocysteine in cardiovascular morbidity and mortality in psoriatic patients.

KEYWORDS: psoriasis, homocysteine, folic acid, cardiovascular disease 
SAŽETAK:

SERUMSKA VRIJEDNOST HOMOCISTEINA U MLADIH BOLESNIKA KOJI NISU PRIMALI SUSTAVNU I BIOLOŠKU TERAPIJU

Uvod: Psorijaza je imunološki posredovana kronična upalna bolest, koja pogađa otprilike 1-3\% populacije u svijetu. Pacijenti oboljeli od psorijaze imaju veću vjerojatnost razvoja kardiovaskularnih bolesti i hiperhomocisteinemije, međutim, ostaje nejasna povezanost serumske razine homocisteina s aktivnošću i trajanjem bolesti.

Cilj ove studije bio je ispitati serumske vrijednosti homocisteina u mladih bolesnika s plak psorijazom, koji nisu do sada primali sustavnu, ili biološku terapiju. Dodatni cilj bio je utvrditi povezanost serumske razine homocisteina s težinom bolesti, razinom upale te razinom folne kiseline i vitamina B12.

Materijali i metode U ovo istraživanje bilo je uključeno 26 ispitanika, uključujući 13 odraslih bolesnika s psorijazom naivnih za sustanu terapiju, bez komorbiditeta, malignih oboljenja i zaraznih bolesti te 13 zdravih, nepovezanih, dobno i spolno usklađenih dobrovoljaca. Težina bolesti i kvaliteta života procijenjena je korišstenjem standardiziranih testova - Psoriasis Area and Severity Index (PASI) i Dermatološkog indeksa kvalitete života (DLQI). Iz venske krvi ispitanika, u rutinskom kliničkom laboratoriju, određena je diferencijalna krvna slika (DKS), brzina sedimentacije eritrocita (SE), C reaktivni protein (hsCRP) te serumske razine homocisteina, vitamina B12 i folne kiseline.

Rezultati Istraživana skupina sastojala se od mladih sudionika, prosječne dobi oko 35 godina. Prema PASI indeksu, težina bolesti bila je u rasponu od blage $(2,10)$ do umjerene $(15,2)$ psorijaze. Nije bilo značajne razlike u vrijednostima hsCRP-a i DKS-a između ispitivanih skupina. Ispitanici s psorijazom imali su statistički značajno više vrijednosti homocisteina u usporedbi sa zdravim ispitanicima, ali nije bilo dokaza hiperhomocisteinemije povezane s psorijazom. Svi ispitanici imali su normalne vrijednosti vitamina B12 i folne kiseline u serumu. Utvrđena je umjerena negativna povezanost između razine homocisteina u serumu i vitamina B12 te razine homocisteina i folne kiseline. Nadalje, serumska razina homocisteina nije bila povezana s hsCRP-om, ukupnim brojem leukocita i trombocita, ali je uočena značajna pozitivna povezanost serumske razine homocisteina i sedimentacije.

Zaključak: Rizik od kardiovaskularnih bolesti treba razmotriti među svim pacijentima oboljelima od psorijaze, bez obzira na njihovu dob i težinu bolesti. Potrebna su veća prospektivna, kontrolirana ispitivanja kao bi se procijenila uloga homocisteina u razvoju kardiovaskularnih bolesti kod psorijatičnih bolesnika.

KLJUČNE RIJEČI: psorijaza, homocistein, folna kiselina, kardiovaskularna bolest

\section{INTRODUCTION}

Psoriasis is an immune-mediated chronic inflammatory disease, affecting approximately $1-3 \%$ of the population worldwide ${ }^{1,2}$. As opposed to the formerly widespread opinion that psoriasis is a skin limited disease, it is now accepted, due to an increasing number of epidemiological publications and evidence-based research, that significant systemic conditions often accompany this chronic disease ${ }^{3}$. In fact, psoriasis is considered as an independent risk factor for cardiovascular morbidity and mortality ${ }^{4,5}$. Particularly, the risk for the development of myocardial infarction, as well as other cardiovascular events, is noticeably increased in patients with severe psoriasis, especially those between 20 and 50 years old 6 .

Even though the association between psoriasis and cardiovascular diseases is lately extensively studied, the exact underlying mechanisms have not yet been uncovered ${ }^{7}$.

As suggested in some previously published studies, elevated serum homocysteine levels might contribute to the cardiovascular risk in psoriatic patients ${ }^{8-10}$.

Homocysteine is sulfur containing amino acid, displaying atherogenic and prothrombotic features. It is produced in the metabolism of the essential amino acid methionine and can be catabolized by re-methylation to methionine in the presence of co-factors folic acid and vitamin B12 or by trans-sulfuration to cysteine in the presence of cofactor vitamin $\mathrm{B} 6^{8,11-15}$. Moreover, homocysteine promotes endothelial dysfunction and, consequently, atherosclerosis by reducing the bioavailability of nitric oxide due to inhibition of nitric oxide synthase (eNOS) and oxidative stress, provokes endothelial cell damage, and leads to a state of chronic inflammation of the endothelium ${ }^{12,16}$.

A meta-analysis of 24 studies showed that psoriatic patients have higher homocysteine serum levels, a greater prevalence of hyperhomocysteinemia and, conversely, have lower serum folate levels compared to controls. Yet, the two groups did not significantly differ in vitamin B12 serum levels ${ }^{10}$.

Rapid keratinocyte proliferation with high mitotic activity of basal cells, along with intestinal malabsorption caused by microscopic inflammatory changes of the intestinal mucosa, might contribute to folate deficiency in patients with psoriasis. Since folic acid is a cofactor in the catabolism of homocysteine, the 
decrease in folate serum levels is therefore one of the causes for hyperhomocysteinemia ${ }^{8,17-20}$.

However, due to inconsistent results from several studies, it still remains unclear whether a correlation between homocysteine levels, disease activity and disease duration exists or not ${ }^{8,9,19,21,22}$. Another potential link between homocysteine and psoriasis lies in epigenetic changes of human leukocyte antigen (HLA) DRB1, a major histocompatibility complex (MHC) II protein $^{23,24}$. Provided that the expression of HLA-DRB1 on antigen presenting cells (APCs) can be altered by aberrant methylation status of the gene, these methylation changes can affect the APCs capability of antigen presentation to $\mathrm{T}$ lymphocytes, the main role of HLA-DRB1 ${ }^{23}$. Indeed, hypomethylation of the promoter region of HLA-DRB1 was found in the epidermis of psoriatic lesions when compared to psoriatic non-lesioned skin, whereas the mean methylation rate of HLA-DRB1 in lesioned skin negatively correlated to Psoriasis Area and Severity Index (PASI) score, suggesting that aberrant methylation of this region might play a role in the pathogenesis of psoriasis ${ }^{23}$. Given the fact that homocysteine, as an intermediate, plays an important role in the methylation cycle, the majority of published data supports the claim that high homocysteine serum levels are associated with global DNA hypomethylation in humans. Since the role of homocysteine in the abnormal methylation pattern seen in psoriatic lesions remains unclear, there is a need for further research to elucidate this ${ }^{15,25}$.

The aim of this study was to investigate serum levels of homocysteine in patients with vulgar psoriasis naïve for conventional systemic and biologic therapy. An additional aim was to determine correlation of homocysteine levels with disease severity, inflammation, and folic acid and vitamin B12 supplies.

\section{MATHERIALS AND METHODS \\ Subjects}

This was a case-control study, including 13 psoriatic patients with clinically diagnosed plaque psoriasis and 13 healthy unrelated, age- and sex-matched control subjects. Subjects were recruited among the patients admitted at the Department of Dermatology and Venereology of the University Hospital Osijek (Croatia). At the time of enrollment, psoriasis patients had a clinically active and histopathological confirmed disease. The disease severity and life quality were assessed using standardized tools - the Psoriasis Area Severity Index (PASI) and Dermatology Life Quality Index (DLQI), respectively ${ }^{26,27}$.

Exclusion criteria for this study were: (1) ongoing systemic therapy for psoriasis (including immunomodulatory therapy, cytostatic, photochemotherapy and phototherapy), (2) concomitant rheumatic and autoimmune diseases (i.e. spondyloarthropathy, rheumatoid arthritis), (3) malignant and infectious diseases, and (4) age (under 18 years). Anthropometric and demographic data, such as body height, body weight, age, gender and parity were assessed using a questionnaire.
The study was reviewed and approved by the Ethical Committee of the University Hospital Osijek (number: R2-9042 / 2018) and the Ethics Committee of the Faculty of Medicine University of Osijek (number: 2158-61-07-18-135). The study was conducted in accordance with Declaration of Helsinki, and all participants signed written informed consent prior inclusion into the study.

\section{Methods}

For the purpose of determining differential blood count, C-reactive protein (hs-CRP), erythrocyte sedimentation rate (ESR), serum levels of homocysteine, vitamin B12 and folic acid, venous blood was collected in the morning, after a minimum of 8-hours fasting period. Samples intended for homocysteine level analysis were immediately put on ice. All samples were delivered to the laboratory at the Clinical Department for Laboratory Diagnostics (University Hospital Osijek, Osijek, Croatia) and analyzed within 1 hour. The normal laboratory range for plasma homocysteine was $0-14 \mu \mathrm{mol} / \mathrm{l}$, and hyperhomocysteinemia was defined as a homocysteine concentration $>14 \mu \mathrm{mol} / \mathrm{l}^{28}$.

\section{Statistical analysis}

All results are reported as the mean \pm standard deviation (SD). The Shapiro-Wilk test was used to test the normality of data distribution. Next, data were compared by Student's t-test or the Mann-Whitney rank-sum test for normally distributed data and data that did not follow a normal distribution pattern, respectively. The correlations between serum levels of homocysteine and other assessed parameters were determined by Pearson's correlation tests. $\mathrm{p}<0.05$ was considered statistically significant. SigmaPlot, version 11.2 (Systat Software, Inc., Chicago, IL, USA) was used for statistical analysis.

\section{RESULTS}

The present study included 26 subjects, of which 13 participants were psoriasis patients with an active disease, and the remaining 13 participants were age- and sex- matched healthy controls. Their demographic and clinical data are shown in Table 1. The average age of enrolled subjects in both groups was around 35 . Disease severity in psoriasis patients was assessed using the PASI index and ranged from 2.10 to 15.2 . The rate of smokers among psoriasis patients and healthy controls was $46.2 \%$ and $23.1 \%$, respectively. C-reactive protein levels and differential blood count did not vary significantly between the groups (Table 1). Psoriasis patients had significantly higher serum levels of homocysteine compared to healthy subjects ( $\mathrm{p}=0.021$; Table 1 and Figure 1), however, there was no evidence of hyperhomocysteinemia related to psoriasis. All included subjects had serum homocysteine levels within the normal reference range except one psoriasis patient who presented with slightly elevated level of homocysteine $(15.5 \mu \mathrm{mol} / \mathrm{L})$, (Table 1$)$.

All subjects had normal serum levels of vitamin B12 and 


\begin{tabular}{|c|c|c|c|c|}
\hline & & Psoriasis patients & Healthy controls & $\begin{array}{c}\text { t test } \\
\text { (p value) }\end{array}$ \\
\hline \multicolumn{2}{|c|}{ Number of participants (N) } & 13 & 13 & - \\
\hline \multirow{2}{*}{ Sex } & Male $(\mathrm{N})$ & 7 & 10 & - \\
\hline & Female $(\mathrm{N})$ & 6 & 3 & - \\
\hline \multicolumn{2}{|c|}{ Age (years) } & $34.3 \pm 7.71(25.0,50.0)$ & $35.9 \pm 8.38(24.0,55.0)$ & 0.630 \\
\hline \multicolumn{2}{|c|}{ PASI } & $9.16 \pm 3.91(2.10,15.2)$ & $\mathrm{N} / \mathrm{A}$ & - \\
\hline \multicolumn{2}{|c|}{ DLQI } & $5.00 \pm 5.85(0.00,20.0)$ & $\mathrm{N} / \mathrm{A}$ & - \\
\hline \multicolumn{2}{|c|}{ BMI } & $24.9 \pm 4.72(19.1,34.9)$ & $25.0 \pm 4.28(19.5,35.8)$ & 0.936 \\
\hline \multirow{2}{*}{ Smoking } & Yes $(\mathrm{N})$ & 6 & 3 & - \\
\hline & No $(\mathrm{N})$ & 7 & 10 & - \\
\hline \multicolumn{5}{|c|}{ Parameter (unit; laboratory referent values) } \\
\hline \multicolumn{2}{|c|}{$\mathrm{CRP}(\mathrm{mg} / \mathrm{l} ;<5.0)$} & $1.86 \pm 2.03(0.30,7.80)$ & $1.41 \pm 1.09(0.12,3.20)$ & 0.488 \\
\hline \multicolumn{2}{|c|}{ Leukocytes (x10e9 /L ; 3.40-9.70) } & $6.77 \pm 1.67(3.7,9.0)$ & $6.18 \pm 1.83(4.50,10.4)$ & 0.402 \\
\hline \multicolumn{2}{|c|}{ Erythrocytes (x10e12/L; 3.86-5.08) } & $4.84 \pm 0.43(4.08,5.34)$ & $5.00 \pm 0.36(4.47,5.73)$ & 0.342 \\
\hline \multicolumn{2}{|c|}{ Thrombocytes (x10e9/L; 158.0-424.0) } & $271.4 \pm 58.8(214.0,416.0)$ & $254.1 \pm 58.1(145.0,391.0)$ & 0.458 \\
\hline \multicolumn{2}{|c|}{ Sedimentation rate $(\mathrm{mm} / 3.6 \mathrm{KS} ; 4.00-24.0)$} & $5.45 \pm 1.69(3.00,8.00)$ & $5.58 \pm 4.83(1.00,15.0)$ & 0.511 \\
\hline \multicolumn{2}{|c|}{ Homocysteine (umol/l) } & $9.99 \pm 2.30(7.10,15.5)$ & $8.03 \pm 1.36(6.10,10.5)$ & $0.021 *$ \\
\hline \multicolumn{2}{|c|}{ Folic acid (nmol/L; 7.0-64.0) } & $13.7 \pm 4.72(7.0,19.7)$ & $15.6 \pm 5.96(8.00,21.8)$ & 0.370 \\
\hline \multicolumn{2}{|c|}{ Vitamin B12 (pmol/L; 138.0-652.0) } & $318.2 \pm 103.2(216.0,602.0)$ & $291.0 \pm 141.6(136.0,479.0)$ & 0.550 \\
\hline $\begin{array}{l}\text { Data are presented } \\
\text { was considered sign }\end{array}$ & The differen & by Student's t-test or 1 & y rank-sum test, whe & te. ${ }^{* *} \mathrm{p}<0.05$ \\
\hline
\end{tabular}

folic acid (Table 1). The mean plasma levels of either vita$\min \mathrm{B} 12(318.2 \pm 103.2 \mathrm{pmol} / \mathrm{L}$ in psoriasis patients versus $291.0 \pm 141.6 \mathrm{pmol} /$ Lin healthy subjects, $\mathrm{p}=0.370$ ), or folic acid $(13.7 \pm 4.72 \mathrm{nmol} / \mathrm{L}$ in psoriasis patients versus $15.6 \pm 5.96 \mathrm{nmo}-$ $1 / \mathrm{L}$ in healthy subjects, $\mathrm{p}=0.550$ ) were not statistically significantly different between two groups. A moderate negative correlation was found between plasma homocysteine level and vitamin B12 $(\mathrm{r}=-0.603, \mathrm{p}=0.004)$ and folic acid $(\mathrm{r}=-0.638, \mathrm{p}=0.002)$. Further- more, homocysteine levels did not correlate to hsCRP ( $\mathrm{p}=0.638)$, total leukocytes $(\mathrm{p}=0.203)$ and thrombocytes count $(\mathrm{p}=0.291)$, but did significantly positively correlate to sedimentation rate $(\mathrm{r}=0.410, \mathrm{p}=0.0159)$

Psoriasis patients included in this study had mild to moderate disease severity. Mean PASI score was 9.16 \pm 3.91 , ranging from 2.10 to 15.2. There is no evidence of direct correlation between current disease severity and serum homocysteine levels 


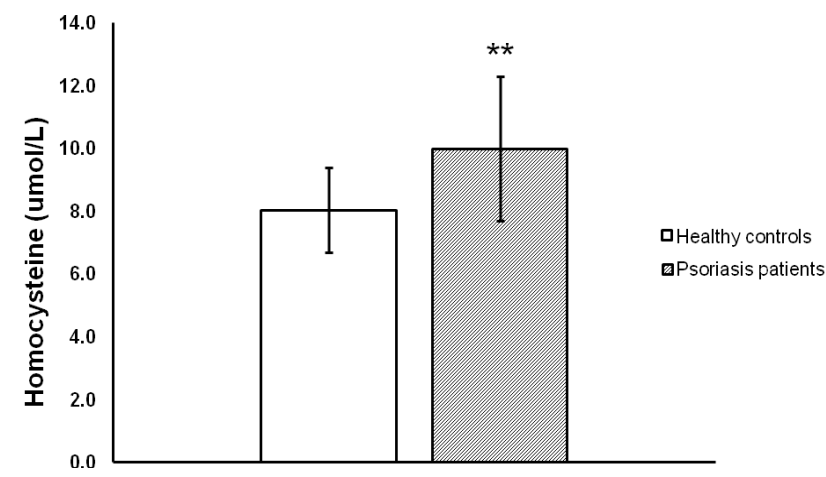

Figure 1. Psoriasis Patients Present with Higher Serum Levels of Homocysteine Compared to Healthy Controls

A

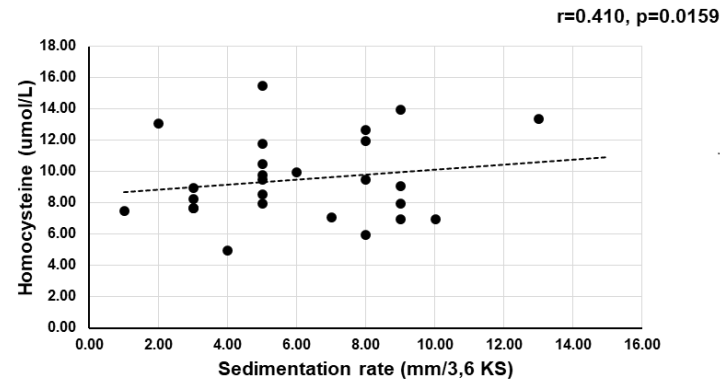

B

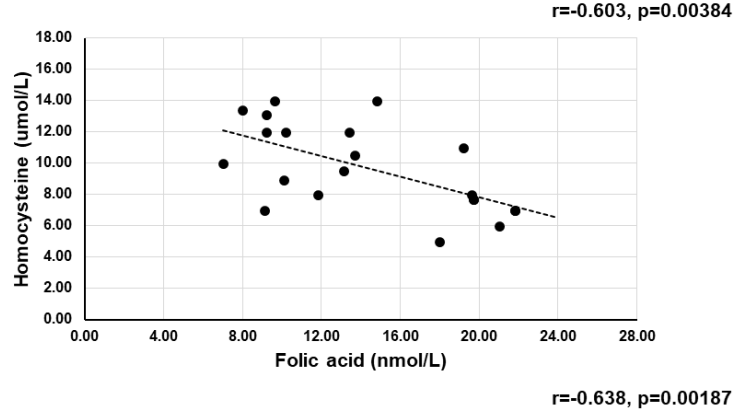

C

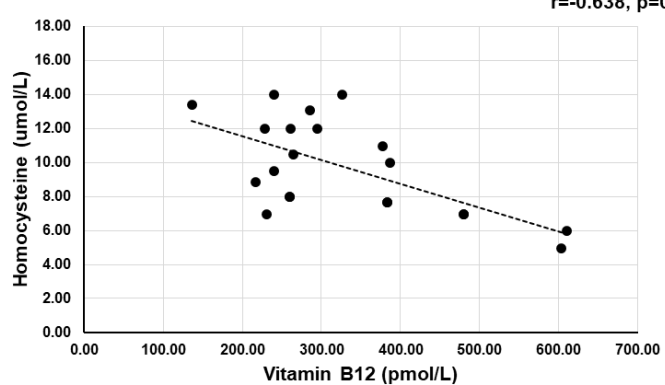

Figure 2. Homocysteine Levels Correlate to Inflammation and Body Supply of Folic Acid and Vitamin $B 12$ $(\mathrm{p}=0.228)$, nor the life quality of psoriasis patients and serum homocysteine levels $(\mathrm{p}=0.392)$.

\section{Discussion}

Psoriasis is considered to be an independent risk factor for cardiovascular morbidity and mortality, but the exact underlying mechanisms have not yet been uncovered ${ }^{3-5}$. Some recent studies suggested that elevated serum homocysteine levels in psoriatic patients might contribute to the cardiovascular risk in psoriatic patients, due to their atherogenic and prothrombotic effect ${ }^{11-15}$. In the present study young psoriasis patients naïve for systemic and biologic therapy presented with significantly higher serum levels of homocysteine compared to the healthy subjects, but still their serum homocysteine levels were within normal reference range. In addition, all participants had normal serum levels of $\mathrm{B} 12$ vitamin and folic acid. These results partly correspond to previous studies that are included in the meta-analysis performed by Tsai TY et $\mathrm{al}^{10}$. The authors reported significantly higher serum homocysteine level in 18 out of 24 studies, a higher prevalence of hyperhomocysteinaemia in seven studies, a lower serum folate level in 14 studies, and no difference in serum vitamin B12 levels between psoriasis patients and the healthy controls ${ }^{10}$. Although serum levels of folic acid between two groups in our research showed no significant difference, we found a moderate negative correlation between the serum homocysteine level and vitamin B12, as well as between plasma homocysteine level and folic acid level. Similar results were found in previous research concerning negative correlation between serum homocysteine levels and folic acid levels, but none of the previous studies showed significant correlation between the serum levels of homocysteine and B12 vitamin ${ }^{10}$. Negative correlation between homocysteine and folic acid as well as homocysteine and B12 vitamin could be related to the fast epidermal overgrowth and higher mitotic basal cell activity of the psoriasis patients ${ }^{20}$. An additional reason for the higher homocysteine levels among psoriasis patients could be the reduced absorption of folic acid and B12 vitamin in the intestine due to micro damage of the intestinal villi that is caused by long term chronic inflammation in psoriatic patients ${ }^{29,30}$. Furthermore, normal folate levels observed in our study, which is contrast to previous reports, might be explained by younger age ( 35 years old) of subjects and shorter exposure to systemic inflammation ${ }^{10}$. Additionally, homocysteine levels did not correlate to hsCRP and total leukocytes count, but did significantly positively correlate to sedimentation rate. Consistent to previous reports, we failed to find direct correlation between current disease severity and serum homocysteine levels ${ }^{10}$. These results suggest that hyperhomocysteinemia and cardiovascular comorbidity rise as a result of prolonged exposure to systemic inflammation.

\section{CONCLUSSION}

Based on the results of the present study, homocysteine has 
the potential as a biomarker of cardiovascular risk in psoriasis patients, primarily during long term follow-up. Single measurements of serum homocysteine levels in population of young psoriasis patients are likely to fall within the normal reference range, and thus could not be used for prediction of cardiovascular

\section{LITERATURE:}

1. Lebwohl MG, Bachelez H, Barker J, Girolomoni G, Kavanaugh A, Langley RG, et al. Patient perspectives in the management of psoriasis: Results from the population-based Multinational Assessment of Psoriasis and Psoriatic Arthritis Survey. J Am Acad Dermatol. 2014 May;70(5):871-81.e1-30. doi: 10.1016/j.jaad.2013.12.018 2. Mcdonald I, Connolly M, Tobin A. AReview ofPsoriasis, a Known Risk Factor for Cardiovascular Disease and Its Impact on Folate AReview ofPsoriasis, a Known Risk Factor for Cardiovascular Disease and Its Impact on Folate and Homocysteine Metabolism Cardiovascular Disease and Its Impact on. J Nutr Metab. 2012;2012(965385). 3. Yeung H, Takeshita J, Mehta NN, Kimmel SE, Ogdie A, Margolis DJ, et al. Psoriasis severity and the prevalence of major medical comorbidity: A population-based study. JAMA Dermatology. 2013;149(10):1173-9.

4. Mehta NN, Azfar RS, Shin DB, Neimann AL, Troxel AB, Gelfand JM. Patients with severe psoriasis are at increased risk of cardiovascular mortality: Cohort study using the general practice research database. Eur Heart J. 2010 Apr;31(8):1000-6. doi: 10.1093/eurheartj/ehp567. 5. Gelfand JM, Dommasch ED, Shin DB, Azfar RS, Kurd SK, Wang $\mathrm{X}$, et al. The risk of stroke in patients with psoriasis. J Invest Dermatol. 2009 Oct;129(10):2411-8. doi: 10.1038/jid.2009.112.

6. Gelfand JM, Neimann AL, Shin DB, Wang X, Margolis DJ, Troxel $A B$. Risk of myocardial infarction in patients with psoriasis. JAMA. 2006 Oct 11;296(14):1735-41.

7. Cozzani E, Rosa GM, Burlando M, Parodi A. Psoriasis as a cardiovascular risk factor: Updates and algorithmic approach. Giornale Italiano di Dermatologia e Venereologia. 2018.

8. Malerba M, Gisondi P, Radaeli A, Sala R, Calzavara Pinton PG, Girolomoni G. Plasma homocysteine and folate levels in patients with chronic plaque psoriasis. Br J Dermatol. 2006 Dec;155(6):1165-9.

9. Giannoni M, Consales V, Campanati A, Ganzetti G, Giuliodori K, Postacchini V, et al. Homocysteine plasma levels in psoriasis patients: our experience and review of the literature. J Eur Acad Dermatology Venereol. 2015;29(9):1781-5.

10. Tsai TY, Yen H, Huang YC. Serum homocysteine, folate and vitamin B 12 levels in patients with psoriasis: a systematic review and meta-analysis. Br J Dermatol. 2019 Feb;180(2):382-389. doi: 10.1111/ bjd.17034.

11. Das M, Dawn I, Sarkar S, Plasma homocysteine levels in patients with Psoriasis. Asian Journal of Medical Sciences, 8(5), 4-7. https://doi. org/10.3126/ajms.v8i5.17136

12. Peterson JC, Spence JD. Vitamins and progression of atherosclerosis in hyper-homocyst(e)inaeamia. Lancet. 1998; DOI:https://doi. org/10.1016/S0140-6736(98)11058-9

13. Debreceni B, Debreceni L. The role of homocysteine-lowering B-vi- risk. In addition, etiology of cardiovascular diseases is complex, including genetic, environmental and other factors thus large prospective controlled studies are needed to overcome immense heterogeneity among them. Here we would like to emphasize

tamins in the primary prevention of cardiovascular disease. Cardiovasc Ther. 2014 Jun;32(3):130-8. doi: 10.1111/1755-5922.12064.

14. Wierzbicki AS. Homocysteine and cardiovascular disease : a review of the evidence. Diab Vasc Dis Res. 2007 Jun;4(2):143-50.

15. Yi P, Melnyk S, Pogribna M, Pogribny IP, Hine RJ, James SJ. Increase in plasma homocysteine associated with parallel increases in plasma S-adenosylhomocysteine and lymphocyte DNA hypomethylation. J Biol Chem. 2000 Sep 22;275(38):29318-23.

16. Lai WKC, Kan MY. Homocysteine-induced endothelial dysfunction. Ann Nutr Metab. 2015;67(1):1-12. doi: 10.1159/000437098. 17. Abedini R, Goodarzi A, Saeidi V, Hosseini SH, Jadidnuri A, Salehi Taleghani M, et al. Serum homocysteine level, vitamin B12 levels, and erythrocyte folate in psoriasis: A case-control study. Int J Women's Dermatology. 2019;5(3):171-4. Available from: https://doi.org/10.1016/j. ijwd.2018.12.004

18. McDonald I, Connolly M, Tobin AM. A review of psoriasis, a known risk factor for cardiovascular disease and its impact on folate and homocysteine metabolism. J Nutr Metab. 2012;2012:965385. doi: $10.1155 / 2012 / 965385$

19. Tobin A, Hughes R, Hand EB, Leong T, Graham IM, Kirby B. Homocysteine status and cardiovascular risk factors in patients with psoriasis : a case - control study. Clin Exp Dermatol. 2011 Jan;36(1):19-23. doi: 10.1111/j.1365-2230.2010.03877.x.

20. Fry L, Macdonald A, Almeyda J, Griffin CJ, Hoffbrand AV. The mechanism of folate deficiency in psoriasis. Br J Dermatol. 1971 Jun;84(6):539-44. DOI: 10.1111/j.1365-2133.1971.tb02543.x 21. Brazzelli V, Grasso V, Fornara L, Moggio E, Gamba G, Villani S, et al. Homocysteine, vitamin B12 and folic acid levels in psoriatic patients and correlation with disease severity. Int J Immunopathol Pharmacol. 2010 Jul-Sep;23(3):911-6.

22. Gisondi P, Tessari G, Conti A, Piaserico S, Schianchi S, Peserico A, et al. Prevalence of metabolic syndrome in patients with psoriasis: A hospital-based case-control study. Br J Dermatol. 2007 Jul;157(1):6873.

23. Zong W, Ge Y, Han Y, Yang X, Li Q, Chen M. Hypomethylation of HLA-DRB1 and its clinical significance in psoriasis. Oncotarget. 2017;8(7):12323-32. doi: 10.18632/oncotarget. 12468

24. Wang WM, Jin HZ. Homocysteine: A Potential Common Route for Cardiovascular Risk and DNA Methylation in Psoriasis. Chin Med J (Engl). 2017;130(16):1980-1986. doi: 10.4103/0366-6999.211895. 25. Mandaviya PR, Stolk L, Heil SG. Homocysteine and DNA methylation: A review of animal and human literature. Mol Genet Metab. 2014;113(4):243-52. Available from: http://dx.doi.org/10.1016/j. ymgme.2014.10.006

26. Feldman SR, Krueger GG. Psoriasis assessment tools in clinical trials. Ann Rheum Dis. 2005 Mar; 64(Suppl 2): ii65-ii68. doi: 10.1136/ 
ard.2004.03123727.

27. Finlay AY, Khan GK. Dermatology Life Quality Index (DLQI)--a simple practical measure for routine clinical use. Clin Exp Dermatol. 1994 May;19(3):210-6.

28. Selhub J, Jacques PF, Wilson PW et al: Vitamin status and intake as primary determinants of homocysteinemia in an elderly population. JAMA, 1993; 270: 2693-98 .

29. Schatteman L, Mielants H, Veys EM et al. Gut inflammation in psoriatic arthritis: a prospective ileocolonoscopic study. J Rheumatol 1995; 22: 680-3.

30. Scarpa R, Manguso F, D’Arienzo A et al. Microscopic inflammatory changes in colon of patients with both active psoriasis and psoriatic arthritis without bowel symptoms. J Rheumatol 2000; 27: 1241-6. 
Original Article 